\title{
Superoxide Dismutase Due to Occupational Metals Exposure to Nickel on Mutant p53 Dental Technicians
}

Titiek Berniyanti ( $\nabla$ titiek-b@fkg.unair.ac.id )

Universitas Airlangga

Marhazlinda Marhazlinda

University of Malaya

Retno Palupi

Universitas Airlangga

Bhetari Dwitya Dhinugrahini

Universitas Airlangga

Research Article

Keywords: ROS, SOD, Good Health, Wild p53, Mutant p53

Posted Date: March 29th, 2022

DOI: https://doi.org/10.21203/rs.3.rs-1337330/v2

License: (a) (i) This work is licensed under a Creative Commons Attribution 4.0 International License.

Read Full License 


\section{Abstract}

\section{Background}

Nickel levels in dental technicians' blood serum are significantly linked to the generation of free radicals and catalyze the development of reactive oxygen species (ROS) (ROS). An increase in ROS causes oxidative stress and a p53 gene mutation. Superoxide dismutases (SODs) are important antioxidant enzymes that help the body fight oxidative stress.

Purpose

The goal of this study is to see if dental technician occupational exposure to Ni contributes to the occurrence of p53 mutations and lower SOD activity in dental technicians.

Methods

Blood samples were taken for 3 types of tests, namely Ni examination, with Atomic Absorbance Spectrophotometry (AAS), p53 mutant protein examination by ELISA method, and examination of SOD enzyme activity by Assay Method.

\section{Result}

The concentration of nickel in dental technicians' blood samples is higher than in controls. Dental technician blood samples have lower levels of SOD than controls. Between dental technicians and controllers, there is a major difference. A negative connection exists between $\mathrm{Ni}$ and SOD, a positive correlation exists between $\mathrm{Ni}$ and p53mutant, and a negative correlation exists between SOD and p53mutant, according to the Spearman correlation test.

Conclusion

A high nickel concentration in the blood serum of a dental worker raises the level of p53 mutants and lowers SOD activity, because p53 mutants have a negative dominant effect on wild p53 types, if wild-type p53 levels decline, p53 mutant levels may rise.

Trial Registration: No: 149 / HRECC.FODM / VIII / 2017.

\section{Introduction}

Dental technicians are at risk of chemical exposure, including metals, acrylic monomers, and free silica particles. The intensity of long exposure to metal and acrylic dust during the finishing and grinding process in the manufacture of dental prostheses can increase the risk of pneumoconiosis, asthma, chronic obstructive pulmonary disease (COPD), cancer, fibrosis, and pulmonary granulomatosis in dental technicians. ${ }^{1-3}$ 
Since they are biocompatible, have high strength, are corrosive resistant, and are relatively less expensive than gold, cobalt-chromium (Co-Cr), and nickel-chromium (Ni-Cr) alloys are commonly used in dentistry for removable partial dentures, porcelain-fused-to-metal crowns, and metal frames. ${ }^{4}$ Metal alloy exposure, as well as improper working conditions and worker protection, is hazardous to worker health during the production process, notwithstanding the benefits.

Research conducted by Sivakumar reported that 53 out of 70 dental technicians had pneumoconiosis due to dust from processing dental materials. One of the metal materials in dental care is Ni. Ni-Cr and Co-Cr, are popularly used by dental technicians to make removable partial dentures, porcelain fuses, and bridges. ${ }^{5}$ The base alloy was chosen to replace the gold (IV) alloy type due to its lower cost. ${ }^{4,6}$ This content is also found in endodontic instruments, metal brackets, curved cables, ribbons, springs, and cable ties.

Occupational $\mathrm{Ni}$ exposure has been linked to a variety of health problems, including skin allergies, pulmonary fibrosis, and lung cancer. Given the importance of $\mathrm{Ni}$ in the development of high-quality dental alloys, evidence-based comprehensive reviews of existing knowledge and understanding of biological reactions and biocompatibility of $\mathrm{Ni}$-containing dental alloys are recommended regularly. Some $\mathrm{Ni}$ compounds are designated as carcinogens to people by inhalation exposure, and $\mathrm{Ni}$ metal particles are classed as carcinogenic materials to humans. ${ }^{7}$

High levels of metals in the blood can cause elevated levels of Reactive Oxygen Species (ROS), reduced enzyme activity on metabolism, and detoxification of Reactive Oxygen Species (ROS). Excessive Reactive Oxygen Species (ROS) can cause oxidative stress and p53 gene mutations that are generally in the form of GC-TA transversion, mitochondrial dysfunction, disruption of the antioxidant system superoxide dismutases (SOD), which are very important antioxidant defenses against oxidative stress in the body, or a combination of these factors improves ROS. ${ }^{8}$

Oxidative stress is a normal phenomenon that occurs in cells or tissues when oxygen radical production exceeds antioxidant capacity. Excess free radicals can damage important macromolecules from cells, cause abnormal gene expression, disruption in receptor activity, cell proliferation or death, immune disorders, and mutagenesis, proteins. Antioxidant enzymes catalyze the decomposition of ROS. ${ }^{9}$ Superoxide radicals are considered the "primary" ROS, being able to interact further with other molecules to produce "secondary" ROS. This can be achieved either directly or indirectly through enzymes or metal catalysis processes. ${ }^{10}$

In response to a free radical associated with oxidative stress, the body has a natural defense system in the form of endogenous enzymes that neutralize and expedite the breakdown of free radical compounds to prevent damage to components of cell macromolecules. Superoxide dismutase (SOD), catalase, and glutathione peroxidase are examples of preventive defense systems, while glutathione peroxidase is an example of antioxidative defense systems. ${ }^{11}$ 
The most significant antioxidant is superoxide dismutase (SOD). SOD catalyzes 02 dismutation for $\mathrm{H} 2 \mathrm{O} 2$ and 02 . SOD is an antioxidant enzyme that plays a role in fighting against superoxide, radical oxygen which is released in the inflammatory pathway and causes connective tissue damage. This enzyme is formed as a homeostatic mechanism to protect tissue and can be detected in extra and intracellular compartments. ${ }^{12}$

The goal of this study is to see if there's a link between nickel metal (Ni) exposure in the workplace and superoxide dismutase enzyme (SOD) activity and p53 mutations in dental technicians. Dental technicians must follow safety protocols and requirements. Personal protection equipment (PPE) such as work clothing, protective masks, protective gloves and goggles, and ventilation are required for dental technicians. The amount of nickel in the air can be reduced by using proper ventilation, exhausters, and filters.

\section{Materials And Method}

This research is an observational analytic study with a Cross-sectional approach, to determine the relationship between nickel $(\mathrm{Ni})$ exposure in the occupational to the activity of the enzyme Superoxide Dismutase (SOD) in dental technicians. Written consent was collected from forty dental technicians who worked on metal prostheses for at least three years. Forty control volunteers were selected from unexposed workers in Surabaya. The control group was never exposed to metal alloys or other chemicals during work or leisure time. All methods were performed in accordance with the relevant guidelines and regulations by Ethics Committee, Faculty of Dental Medicine, Universitas Airlangga, Surabaya, Indonesia (Number: 149 / HRECC.FODM / VIII / 2017).

\section{Measurement of Nickel-metal concentration}

Venous blood samples were collected from dental technicians by a professional nurse and placed in evacuated metal-free tubes. Blood samples were taken in $4 \mathrm{~mL}$ vials, $3 \mathrm{~mL}$ for nickel-metal concentration testing, and $1 \mathrm{~mL}$ for TP53 mutant level measurement. Using a disposable needle, blood samples were obtained intravenously. Blood samples were inserted in vacuum tubes with anticoagulants to assess nickel metal content. In the meantime, blood samples were placed in plain vacuum tubes to determine the level of TP53 mutant. After coagulation for 10 minutes at room temperature, a serum is collected forming centrifugation at $1000 \mathrm{~g}$ for 15 minutes. Serum samples are frozen at $-80 \mathrm{oC}$ while waiting for the examination time. Metal levels were measured using Atomic Absorbance Spectrophotometry (AAS) with a wavelength of $357.9 \mathrm{~nm}$ at the Regional Health Laboratory in Surabaya. The result was expressed in $\mathrm{g} / \mathrm{L}$ units. Levels of TP53 mutants were measured.

\section{Measurement of TP53 mutant level}

An ELISA TP53 Kit ELISA Mutant Kit (Competitive ELISA) from MyBioSource.com was used to measure the TP53 mutant level. A monoclonal anti-TP53 antibody and a TP53-HRP conjugate are used in the TP53 ELISA kit to produce a competitive enzyme immunoassay. In a pre-coated plate, the assay sample 
and buffer are incubated with the TP53-HRP conjugate for one hour. After the incubation period, the wells are decanted and washed five times. Following that, the wells are treated with an HRP enzyme substrate. As a result of the enzyme-substrate reaction, a blue-colored complex formed. Finally, to bring the reaction to an end, a stop solution is added, coloring the solution yellow in the process. The color intensity is spectrophotometrically quantified at $450 \mathrm{~nm}$ in a microplate reader. The unit of measurement for TP53 mutant levels is the unit/OD.

\section{Measurement of the enzyme Superoxide Dismutase activity (SOD)}

EDTA was used to obtain blood samples. Centrifuge the plasma layer and transfer it to a new tube without disturbing the buffy layer, then store it at $-80^{\circ} \mathrm{C}$ until ready to analyze. The buffy covering on red blood cell pellets should be removed. Centrifuge erythrocyte membrane pellets after resuspending erythrocytes in 5 times the volume of cold distilled water. Until ready to analyze, keep the supernatant at $-80^{\circ} \mathrm{C}$. Before the SOD test, plasma can be diluted 3 to 10 times, and red blood cell lysate can be diluted 100 times. The SOD Activity Assay Kit is used to examine blood samples.

\section{Preparation of Reagents and Storage Conditions:}

For the WST Work Solution, dilute $1 \mathrm{~mL}$ of WST solution with $19 \mathrm{~mL}$ of Buffer Solution Assay. The diluted solution is stable for up to 2 months at $4^{\circ} \mathrm{C}$. Before using the enzyme solution, centrifuge it for 5 seconds. Combine the components thoroughly with a pipette (this step is necessary because the enzyme has two layers and must be mixed well before dilution). $2.5 \mathrm{~mL}+15 \mathrm{~mL}$ Dilute Buffer The aqueous enzyme solution can persist for up to 3 weeks at $4^{\circ} \mathrm{C}$.

\section{SOD Testing Protocol}

Add $20 \mathrm{I}$ of sample solution to each sample and blank 2 as needed, and $20 \mathrm{I}$ of $\mathrm{H} 20$ to each blank 1 and blank 3 as needed (See Table 1). Each 200 I of WST Work solution should be added. For each blank 2 and blank 3 , add 20 I of dilution Buffer. For each sample, add 20 I of Work enzyme solution, and make sure that blank 1 is good.

Table 1. Sample SOD Testing Protocol

\begin{tabular}{|lllll|}
\hline & Sample & Blank 1 & Blank 2 & Blank 3 \\
\hline Sample solution & $20 \mu \mathrm{l}$ & & $20 \mu \mathrm{l}$ & \\
\hline ddH2O & & $20 \mu \mathrm{l}$ & $20 \mu \mathrm{l}$ \\
\hline WST Working Solution & $200 \mu \mathrm{l}$ & $200 \mu \mathrm{l}$ & $200 \mu \mathrm{l}$ & $200 \mu \mathrm{l}$ \\
\hline Enzyme Working Solution & $20 \mu \mathrm{l}$ & $20 \mu \mathrm{l}$ & \\
\hline Dilution Buffer & & & $20 \mu \mathrm{l}$ & $20 \mu \mathrm{l}$ \\
\hline
\end{tabular}


Note: Because superoxide will be released immediately after each enzyme well's working solution is added, employ multiple pipette channels to avoid each other's reaction lag time. Incubate the plates for 20 minutes at $37^{\circ} \mathrm{C}$. Using a microplate reader, measure the absorbance at $450 \mathrm{~nm}$. Using the equation below, calculate SOD activity (percent inhibition rate).

SOD Activity (inhibition rate $100 \%)=\frac{\left(A_{\text {blank } 1}-A_{\text {blanks }}\right)-\left(A_{\text {sample }}-A_{\text {blank } 2}\right)}{\left(A_{\text {blank1 }}-A_{\text {blanks }}\right)} \times 100$

\section{Statistical analysis}

Ni metal levels and SOD (Superoxide Dismutase) levels in dental technicians and control groups were determined using mean and standard deviation. Statistical software was used to analyze the data (IBM SPSS 16, New York). The Mann-Whitney U test was utilized for the different tests, while the Spearman Test was employed for the correlation test.

\section{Result}

Data observed as shown in Table 2 and Table 3.

Table 2

The results of the test for differences in levels of Ni with mutant SOD and p53 in samples of dental technicians and controls.

\begin{tabular}{|c|c|c|c|c|c|c|}
\hline & $\mathrm{Ni} \mu \mathrm{g} / \mathrm{l}$ & & SOD & & p53 mutan & \\
\hline Grup & Average $\pm S D$ & $\mathrm{P}$ & Average $\pm S D$ & $\mathrm{P}$ & Average $\pm S D$ & $\mathrm{p}$ \\
\hline Dental Technicians & $70,18 \pm 41,86$ & \multirow[t]{2}{*}{0,00 * } & $13,68 \pm 14,76$ & \multirow[t]{2}{*}{0,00 * } & $0,70 \pm 0,21$ & \multirow[t]{2}{*}{$0,014^{*}$} \\
\hline Control & $6,60 \pm 5,96$ & & $72,41 \pm 10,49$ & & $0,58 \pm 0,20$ & \\
\hline
\end{tabular}

Ni levels in dental technicians $(70.18 \pm 41.86)$ were higher than in controls $(6.60 \pm 5.96)$, significantly different from the $p$-value $=0.00$. SOD levels in dental technicians $(13.68 \pm 14.76)$ were lower than controls $(72.41 \pm 10.49)$, significantly different from $p=0.00$. The levels of $p 53$ in dental technicians $(0.70 \pm 0.21)$ were higher than in controls $(0.58 \pm 0.20)$, significantly different from the $p$-value $=0.014$. The prevalence data based on respondents showed in Fig. 1 and Fig. 2. 
Table 3

The correlation test results between levels of $\mathrm{Ni}, \mathrm{SOD}$, and p53 mutants

\begin{tabular}{|lllllll|}
\hline Variable & Ni & & SOD & & \multicolumn{2}{c|}{ p53 mutant } \\
\hline & $\mathrm{p}$ & $\mathrm{r}$ & $\mathrm{P}$ & $\mathrm{r}$ & $\mathrm{p}$ & $\mathrm{r}$ \\
\hline $\mathrm{Ni}$ & & & $0,00^{*}$ & $-0,732$ & $0,031^{*}$ & 0,257 \\
\hline SOD & $0,00 *$ & $-0,732$ & & & $0,004^{*}$ & $-0,336$ \\
\hline p53 mutan & $0,031^{*}$ & 0,257 & $0,004^{*}$ & $-0,336$ & \\
\hline p = p value; $r$ = Correlation Coefficient (strong correlation) \\
\hline * = Significant relationship \\
\hline
\end{tabular}

The correlation test results between $\mathrm{Ni}$ and SOD showed a significant relationship $(p=0.00)$ with a strong correlation value of -0.732 (strong relationship). Correlation test results between $\mathrm{Ni}$ and p53 mutants showed a significant relationship $(p=0.031)$ with a strong correlation value of $r=0.257$ (weak relationship), positively related. Correlation test results between SOD and p53 mutants showed a significant relationship $(p=0.004)$ with a strong correlation value of $r=-0.336$ (weak relationship), negatively related.

\section{Discussion}

The results of our study showed that the dental technician's Ni was higher than the control group, this was due to the accumulation of Ni metal during the continuous denture manufacturing process. 5,13 Denture materials in dentistry consist of metal alloys containing $\mathrm{Ni}$, including base alloys such as $\mathrm{Ni}-\mathrm{Cr}$ and Co-Cr alloys for the manufacture of metal frames for removable partial dentures, crowns, and bridges. Dentures in dental laboratories are performed by dental technicians. ${ }^{14} \mathrm{Ni}-\mathrm{Cr}$ and $\mathrm{Co}-\mathrm{Cr}$ alloys were chosen to replace type IV gold alloys because of their lower cost. ${ }^{15,16} \mathrm{Ni}$ can enter the technician's body via inhalation, oral, and skin. Inhalation exposure through the respiratory tract is the main route of entry of metals into the human body. This shows that dental technicians are at great risk of being exposed to metals while working. ${ }^{17}$

Nickel metal compounds can be carcinogens for humans. ${ }^{18}$ Exposure to this metal, obtained from the work environment of dental technicians causes a high metal build-up in the blood of dental technicians and can interfere with cellular reactions. ${ }^{5}$ These compounds can produce $(\cdot . \mathrm{OH}) \mathrm{H}_{2} \mathrm{O}_{2}$ and $\mathrm{O}_{2}$ through the Fenton and Haber-Weis reaction. Accumulation of genotoxic metals can increase the number of Reactive Oxygen Species (ROS), which normally exist in all aerobic cells in balance with biochemical antioxidants. The hydroxyl radical may cause DNA damage. ${ }^{12}$

The accumulation of nickel can deactivate prolyl hydroxylases (PhD), which are enzymes that act on sensitivity to oxygen molecules. In carrying out its function, PhD requires oxygen and iron. In the presence 
of oxygen, proline 564 in the HIF-1 sub-unit is hydroxylated by PhD. Nickel plays a role in replacing iron and inactivating the PhD enzyme, resulting in hypoxia. ${ }^{19}$ HIF-1 can inhibit p53wild activity in mild hypoxia conditions by downregulating the homeodomain-interacting tumor suppressor protein kinase-2 (HIPK2). In response to DNA damage, HIPK2 phosphorylates p53 at serine 46, activating its apoptotic activity. The GADD45 (Growth Arrest and DNA Damage Inducible Protein) target gene is not activated as a result of the decrease in p53. GADD45 is a DNA repair gene. DNA repair is impossible if GADD45 is not activated. Chromosome damage occurs when DNA repair is inhibited, which has an impact on the formation of micronuclei. MN formation can be induced by a variety of genotoxic chemicals, which can result in cell death, genomic instability, or cancer development. ${ }^{20}$

The apoptotic process due to nickel exposure will also involve ROS. Evidence suggesting the involvement of ROS in apoptosis includes, increase in ROS or elimination of endogenous antioxidants. ${ }^{21} \mathrm{An}$ imbalance between pro-oxidant and antioxidant states will result as a result of the free radical damage. In the process of carcinogenesis, this imbalance is very important. The initial line of defense against free radicals is Superoxide Dismutase (SOD). ${ }^{22}$ When this critical balance is disturbed due to excess ROS, or depletion of antioxidants, or both, oxidative stress occurs. ROS can cause Guanine-Thymine transvers mutations of p53 gene ${ }^{21}$ and lead to low expression of the wild type p53 protein. This backs with our findings, which reveal that wild-type p53 protein levels are lower than mutant p53. The mutant p53 protein exerts a negative dominant impact on wild type p53 proteins by inhibiting the wild-type p53 protein, resulting in p53 protein function inactivation. The finding is thought to be linked to a mutation in the p53 gene. ${ }^{23,24}$ In the wild, the TP53 gene was involved in DNA repair, cell cycle arrest, and apoptosis. There will be chromosomal damage if DNA repair is impeded, which will affect the creation of micronuclei.

The results of statistical tests that have been carried out in this research between nickel levels and superoxide dismutase (SOD) levels in dental technicians and controls, resulted in a significant negative correlation. The greater the Nickel content, the lower the Superoxide Dismutase (SOD) level. Statistical data obtained indicates there is a strong relationship. These results are consistent with the results of 21 studies that measured indicators of oxidative stress such as levels of enzyme activity of Malondialdyde (MDA) and Superoxide Dismutase (SOD) and their relationship to copper and arsenic levels in copper smelters, which showed the average serum levels of copper, arsenic, and MDA were found to be statistically higher, whereas the mean SOD enzyme activity levels were statistically lower among the exposed workers compared to the controls. In this study the the levels of Superoxide Dismutase (SOD) in dental technicians were lower than in the control group, and were significant difference. Stastistic test showed a significant correlation between SOD and TP53 mutant due to higher level of metal. p53wild was lower because of the TP53 mutant dominant effect.

The decrease in SOD activity in dental technicians exposed to metals compared to the control group may be related to the use of SOD in scavenging free radicals because SOD catalyzes the reduction from 
superoxide radicals $(\mathrm{O} 2 \cdot-)$ to Hydrogen Peroxide $(\mathrm{H} 2 \mathrm{O} 2)$, which will then be converted by another antioxidant, namely GPx. or Catalase. ${ }^{22}$

SOD is included as a primary antioxidant that works by preventing the formation of new free radical compounds or converting free radicals that have been formed into less reactive molecules. One of the reasons for decreased SOD was due to nickel exposure. SOD has a function as an antidote to free radicals. If the nickel level in the human body is not high, the body can form a homeostasis process that will overcome the free radicals formed by nickel, one of which is the SOD enzyme. However, if the nickel level is high, the homeostasis process will not be formed which causes SOD activity to decrease.

\section{Conclusion}

A high nickel concentration in the blood serum of a dental worker raises the level of p53 mutants and lowers SOD activity, because p53 mutants have a negative dominant effect on wild p53 types, if wildtype p53 levels decline, p53 mutant levels may rise.

\section{Declarations}

\section{ACKNOWLEDGMENTS}

The authors would like to express their gratitude to the Rector, the Director of the Research and Innovation Center, the Dean, and the Department of Dental Public Health, Faculty of Dental Medicine, Universitas Airlangga, as well as dental technicians that assisted in the completion of this study.

\section{Authors' contributions}

TBy* (0000-0002-2183-1140) drafted the manuscript,

RP (0000-0001-5747-8521) analyzed the data. interpreted the data

BDD (0000-0002-9170-5991) Collected the data.

MAR, (0000-0003-1177-1508) Interpreted the data, Wrote the report experiments

TBy*, RP, and BDD planned the study and participated in the study design.

TBy* and all coauthors contributed substantially to its revision. All authors read and approved the final version of the manuscript.

\section{Funding}

This study was funded by a grant from the Ministry of Higher Education's Skim Competence Research Grants Program, which ran from 2016 to 2017 (grant number: 004/ADD/SP2H/LT/DRPM/VIII/2017). The 
sponsor had no involvement in the study design, data collection, data analysis and interpretation, manuscript creation, or the decision to publish the paper.

\section{Availability of data and materials}

The data used in this study isn't available to the general public. On reasonable request, they can be obtained from the corresponding author.

\section{Ethics approval and consent to participate}

Following receiving ethical authorization from the Health Research Ethics Committee of the Faculty of Dental Medicine, Universitas Airlangga, Surabaya, Indonesia (Number: 271/KKEPK.FKG/ XI/2016), a cross-sectional study was undertaken. Written informed consents were obtained from 40 dental technicians who have worked on the metal prosthesis in the Dental Laboratory Surabaya, Indonesia, for at least three years. All of the subjects were able to comprehend and assent to the study's conditions, and they gave written informed consent. The surveys were used to obtain personal information from dental technicians.

\section{Consent for publication}

Not applicable.

\section{Competing interests}

The authors declare that they have no competing interests.

\section{References}

1. Alavi A, Shakiba M, Nejad AT, Massahnia S, Shiari A. Respiratory findings in dental laboratory technicians in rasht (North of Iran). Tanaffos. 2011;10(2):44.

2. Petrović $D$, Krunić N, Kostić M. Risk factors and preventive measures for occupational diseases in dental technicians. Vojnosanitetski pregled. 2013;70(10):959-63.

3. Shahsavari F, Ghasemi SH, Farhadi SA, Delavari S, Mazinani P. Occupational exposure in dental laboratory technicians may induce nuclear abnormalities in buccal mucosa cells: a preliminary study. Journal of Research in Dental and Maxillofacial Sciences. 2016;1(2):23-7.

4. Berniyanti T, Palupi R, Kriswandini IL, Bramantoro T, Putri IL. Suitability of MDA, 8-OHdG and wildtype p53 as genotoxic biomarkers in metal ( $\mathrm{Co}, \mathrm{Ni}$ and $\mathrm{Cr}$ ) exposed dental technicians: a crosssectional study. BMC oral health. 2020;20(1):1-2.

5. Sivakumar I, Arunachalam KS, Solomon EG. Occupational health hazards in a prosthodontic practice: review of risk factors and management strategies. The journal of advanced prosthodontics. 2012;4(4):259-65. 
6. Setcos JC, Babaei-Mahani A, Di Silvio L, Mjör IA, Wilson NH. The safety of nickel containing dental alloys. Dent Mater. 2006;22(12):1163-8.

7. Larasputri I, Berniyanti T, Diyatri I. Analysis of TP53 Mutants Due to Chromium Metal Exposure on Dental Technicians at Surabaya Laboratory. Journal of International Dental and Medical Research.2009;11(3):950-4.

8. Latvala S, Hedberg J, Di Bucchianico S, Möller L, Odnevall Wallinder I, Elihn K, Karlsson HL. Nickel release, ROS generation and toxicity of $\mathrm{Ni}$ and $\mathrm{NiO}$ micro-and nanoparticles. PloS one. 2016;11(7):e0159684.

9. Ismail HI, Chan KW, Mariod AA, Ismail M. Phenolic content and antioxidant activity of cantaloupe (Cucumis melo) methanolic extracts. Food chemistry. 2010;119(2):643-7.

10. Jomova K, Vondrakova D, Lawson M, Valko M. Metals, oxidative stress and neurodegenerative disorders. Molecular and cellular biochemistry. 2010;345(1):91-104.

11. Valko MM, Morris H, Cronin MT. Metals, toxicity and oxidative stress. Current medicinal chemistry. 2005;12(10):1161-208.

12. Hariyani N, Berniyanti T, Setyowati D. Effects of occupational environmental controls on the level of $\mathrm{Co}, \mathrm{Ni}$ and $\mathrm{Cr}$ among dental technicians. International Journal of Environmental Science and Development. 2015;6(9):643-7.

13. Torbica N, Krstev S. World at work: Dental laboratory technicians. Occupational and environmental medicine. 2006;63(2):145-8.

14. Anusavice KJ, Shen C, Rawls HR. Phillips' Science of Dental Materials. Elsevier Health Sciences; 2013.

15. Rohmaniar PD, Berniyanti T, Rahayu RP. The correlation between the use of personal protective equipment and level wild-type p53 of dental technicians in Surabaya. Dent J (Majalah Kedokt Gigi). 2017;50(1):19-22.

16. Van Noort R, Barbour M. Introduction to Dental Materials. Elsevier Health Sciences; 2014.

17. Escobar J, Varela-Nallar L, Coddou C, Nelson P, Maisey K, Valdés D, Aspee A, Espinosa V, Rozas C, Montoya M, Mandiola C. Oxidative damage in lymphocytes of copper smelter workers correlated to higher levels of excreted arsenic. Mediators Inflamm. 2010;2010.

18. Lu H, Shi X, Costa M, Huang C. Carcinogenic effect of nickel compounds. Molecular and cellular biochemistry. 2005;279(1):45-67.

19. Luzhna L, Kathiria P, Kovalchuk O. Micronuclei in genotoxicity assessment: from genetics to epigenetics and beyond. Frontiers in genetics. 2013;4:131.

20. Salnikow K, Davidson T, Zhang Q, Chen LC, Su W, Costa M. The involvement of hypoxia-inducible transcription factor-1-dependent pathway in nickel carcinogenesis. Cancer research. 2003;63(13):3524-30.

21. Sirisha CV, Manohar RM. Study of antioxidant enzymes superoxide dismutase and glutathione peroxidase levels in tobacco chewers and smokers: A pilot study. Journal of cancer research and 
therapeutics. 2013;9(2):210.

22. El Safty A, Rashed L, Samir A, Teleb H. Oxidative stress and arsenic exposure among copper smelters. British Journal of Medicine and Medical Research. 2014;4(15):2955.

23. Nita M, Grzybowski A. The role of the reactive oxygen species and oxidative stress in the pathomechanism of the age-related ocular diseases and other pathologies of the anterior and posterior eye segments in adults. Oxid Med Cell Longev. 2016;2016.

24. Phalen RN, Le T, Wong WK. Changes in chemical permeation of disposable latex, nitrile, and vinyl gloves exposed to simulated movement. J Occup Environ Hyg. 2014;11(11):716-21.

\section{Figures}

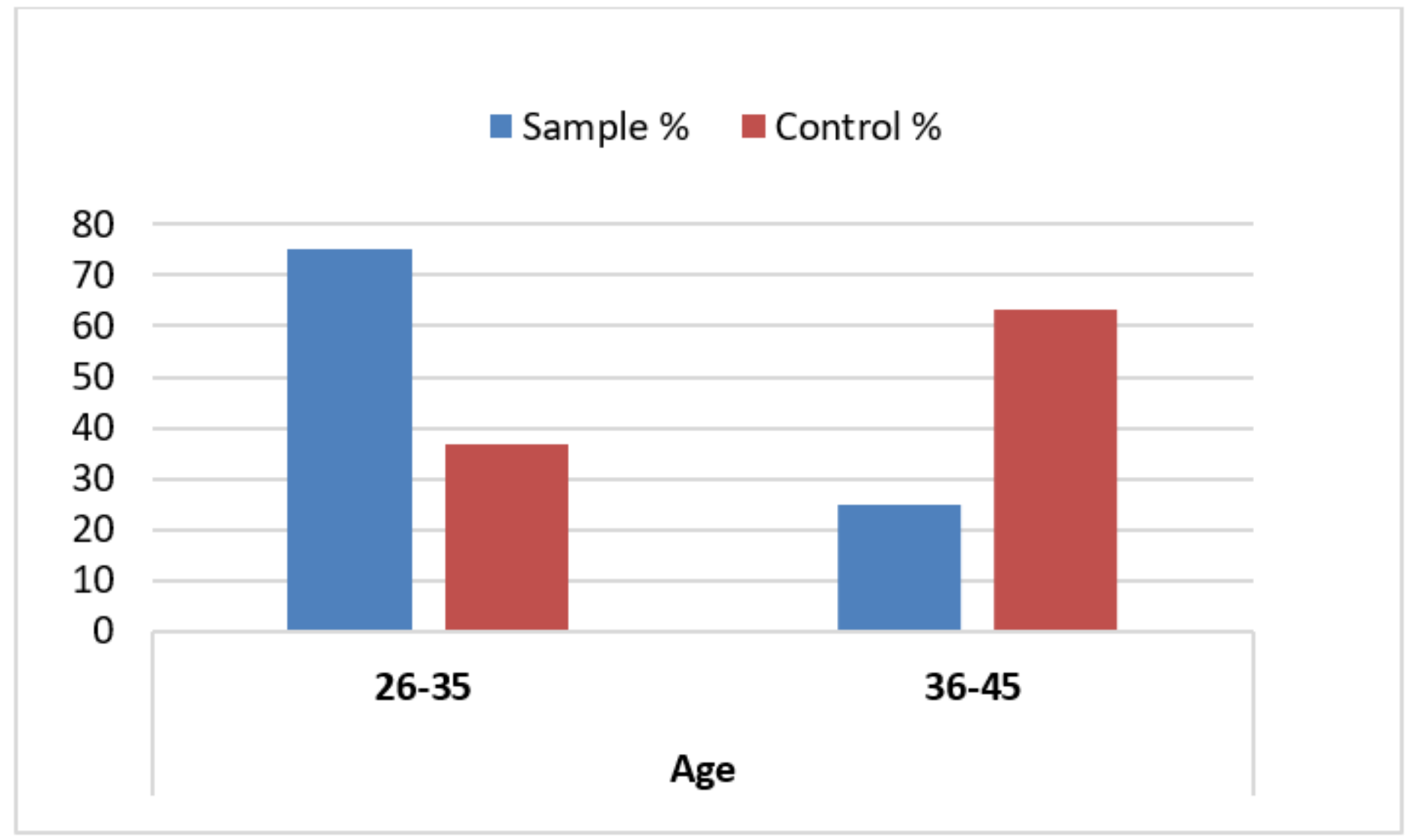

\section{Figure 1}

Characteristics of Respondents based on age. The highest age was in the sample, which is age category 26-35 years. The lowest age is in the control with the age category of 36-45 years. 


\section{- Sample \% control \%}

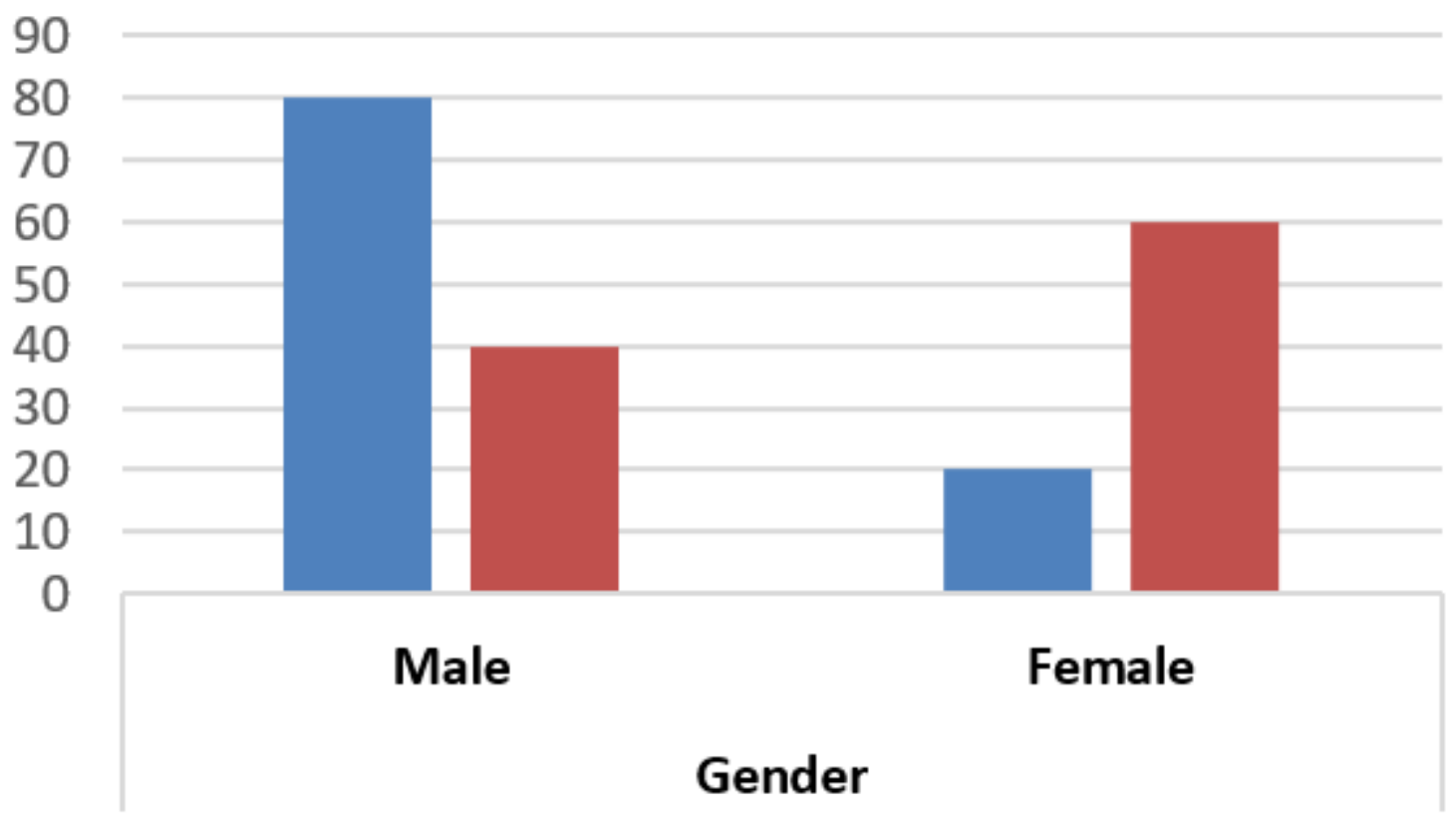

Figure 2

Characteristics of Respondents based on Gender. The highest prevalence gender was in the male category of sample $80 \%$. The lowest prevalence is in the male category control of $20 \%$. 